UDC 661.1:615.4;678.6;677.4-036

\author{
O.V. Maikovych, N.G. Nosova, M.V. Yakoviv, I.A. Dron, A.V. Stasiuk, V.Ya. Samaryk, \\ S.M. Varvarenko, S.A. Voronov
}

\title{
COMPOSITE MATERIALS BASED ON POLYACRYLAMIDE AND GELATIN REINFORCED WITH POLYPROPYLENE MICROFIBER
}

\author{
Lviv Polytechnic National University, Lviv, Ukraine
}

\begin{abstract}
The conditions for preparation of a composite hydrogel based on polyacrylamide and gelatin, which is reinforced with polypropylene microfiber, were determined to increase its strength. The conditions of modification of polypropylene microfiber were established under which its surface is hydrophilized, which was confirmed by a significant increase in the water retention of microfiber by 11.0-15.2 times. Under the same conditions, an increase in the values of the hydrogen component of free surface energy on planar samples of polypropylene was observed (from $2.8 \pm 1.0 \mathrm{mN} \mathrm{m}^{-1}$ to $29.8 \pm 1.0 \mathrm{mN} \mathrm{m}^{-1}$ ). Optimal conditions (minimum limits of component concentrations, temperature range, and $\mathrm{pH}$ of a medium) were determined, under which a hydrogel based on polyacrylamide and gelatin with satisfactory physicochemical and mechanical properties can be formed. A composite hydrogel, based on polyacrylamide and gelatin reinforced with modified polypropylene microfiber, was prepared. It was found that the introduction of modified microfiber increases the limits of the beginning of destruction from $20-30$ to $130 \mathrm{kPa}$. The results of the investigation of the drug release from the hydrogel indicated that the obtained composites can be used as matrices to create a hydrogel therapeutic bandages with the function of prolonged drug delivery.
\end{abstract}

Keywords: hydrogel; polyacrylamide; gelatin; polypropylene; microfiber; drug delivery.

DOI: $10.32434 / 0321-4095-2021-134-1-45-54$

\section{Introduction}

Healing of skin lesions (wounds, burns, and ulcers) is a rather complex process which is influenced by several internal and external factors. The main external factors that influence the speed of healing are as follows: protection of the wound from secondary injury, access of oxygen to the wound surface, lack of destructive interaction between the wound surface and the surface of the bandage; drug delivery; removal of exudate, etc. [1,2]. In recent decades, traditional methods of wound healing have undergone major changes. Among a number of the newest techniques, wet method of wounds healing practice has begun to spread. The most convenient implementation of this method in practice can be done with new types of dressings, such as hydrogel bandages. They have several significant advantages over traditional gauze bandages. Hydrogel-based bandages regulate the heat and water balance of the wound, increase the period between dressings in several times and do not cause pain when replacing them, ensuring patient comfort. In addition, the hydrogel bandages can provide prolonged delivery of therapeutic drugs to the site of damage. Moreover, due to their transparency, it is possible to visually monitor the wound healing process $[3,4]$. The application of hydrogel bandages in the treatment of burns accelerates healing by 6 days as compared with a group of patients treated with traditional gauze dressings [5].

Recently, there has been a trend towards the creation of hydrogel-based bandages, the polymer framework of which includes fragments of biopolymers. This promotes the bio-resorption of the bandages after their intended use and transfers these objects into the category of the so-called «green chemistry».

However, the general disadvantage of hydrogels, which significantly limits their use in many industrial branches, including the creation of hydrogel therapeutic bandages, is their unsatisfactory mechanical properties. Known approaches to increase 
the strength of polymer hydrogels involve increasing the number of crosslinks in their polymer framework; however, this usually results in a significant deterioration in other important characteristics (reduction of the rate and equilibrium of swelling degree, the ability to sorb and release drugs). Improvement of mechanical properties without changing other characteristics of the hydrogel can be achieved by introducing an additional reinforcing element (polymer fiber, mesh or fabric) into the hydrogel $[6,7]$.

The aim of the study was to create a composite hydrogel based on polyacrylamide and gelatin, reinforced with polypropylene microfiber.

The formation of hydrogel material reinforced with polypropylene microfiber (matrix for creation a hydrogel treatment bandage) results from simultaneous interchain reactions. In general, it is a covalent interaction and crosslinking of prepolymers of acrylamide, gelatin and functional groups on the surface of modified polypropylene fibers (Fig. 1). These processes occur due to reactive groups of poly$\mathrm{N}$-(hydroxymethyl)acrylamide. They interact with amino- and amide groups (which are in polyacrylamide and gelatin) both on the surface (from the modification layer) and in volume. It leads to formation of a three-dimensional grid of the polymer framework of the hydrogel. After modification on the surface of polypropylene, fibers are located as fragments of macromolecules with groups that are able to participate in the structuring processes. As a result, the covalent fixation of the polymer framework of the hydrogel to the surface of the fiber occurs.

\section{Experimental}

\section{Reagents}

Acrylamide $(\geq 99 \%)$, gelatin $(\geq 95 \%)$,

formaldehyde ( $\geq 99 \%)$ manufactured by SigmaAldrich were used without any further purification. A copolymer of $\mathrm{N}$-[(tert-butyl peroxy)methyl]acrylamide with octyl methacrylate (PA-OMA) was synthesized according to the methods described elsewhere $[8,9]$. Polypropylene microfiber was $6 \mathrm{~mm}$ long and 0.1 $\mathrm{mm}$ in diameter. Polypropylene plates were produced by Hostalen 0180 D, Elenac (Germany).

The synthesis of polyacrylamide (PAA) and poly$\mathrm{N}$-(hydroxymethyl) acrylamide

Polyacrylamide (PAAm) with various molecular weights $\left(40 \cdot 10^{3}, 50 \cdot 10^{3}\right.$, and $\left.60 \cdot 10^{3} \mathrm{~g} / \mathrm{mol}\right)$ was synthesized by free radical polymerization of acrylamide. To a solution of acrylamide $(100 \mathrm{~g})$ and thioglycolic acid $(0.8,0.6$ or $0.4 \mathrm{~g})$ in water $(499.2$, 499.4 or $499.6 \mathrm{~mL}$, respectively), ammonium persulfate $(0.2 \mathrm{~g})$ was added in an argon medium. The solution was stirred at $50^{\circ} \mathrm{C}$ for $3-4 \mathrm{~h}$. PAAm was isolated by precipitation into methanol from the aqueous solution and then purified by triple reprecipitation. The purified polymer was dried to a constant weight in vacuum at ambient temperature. Poly-N-(hydroxymethyl) acrylamide (pHMAAm) was synthesized from polyacrylamide and formaldehyde. To a solution of polyacrylamide $(25 \mathrm{~g})$ in water $(475 \mathrm{~mL}), \mathrm{NaOH}$ was added to achieve $\mathrm{pH} 9$, and then a $20 \%$ formaldehyde solution $(57 \mathrm{~mL})$ at $40^{\circ} \mathrm{C}$ was introduced. The reaction mixture was stirred at $40^{\circ} \mathrm{C}$ for $3 \mathrm{~h}$ [10]. Unreacted formaldehyde used in the synthesis pHMAAm was removed by reprecipitation. microfiber

Modification of the surface of polypropylene

Grafting of PA-OMA and polyacrylamide chains was performed according to the methods described elsewhere [11]. The obtained polypropylene

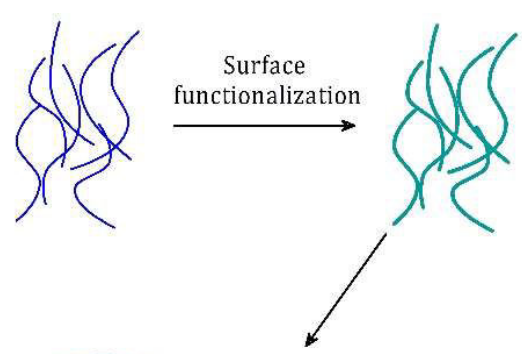

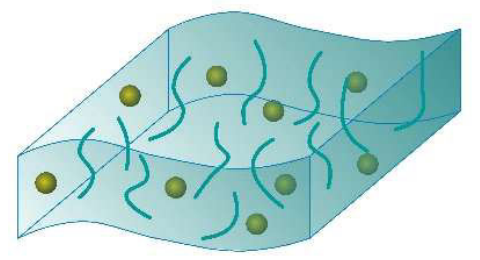

Hydrogel medical bandage

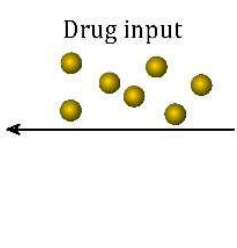

Fig. 1. Scheme of formation of a hydrogel therapeutic bandage reinforced via polypropylene microfiber using combined hydrogel based on polyacrylamide, poly-N-(hydroxymethyl) acrylamide and a natural polymer of protein nature

O.V. Maikovych, N.G. Nosova, M.V. Yakoviv, I.A. Dron, A.V. Stasiuk, V.Ya. Samaryk, S.M. Varvarenko, 
microfibers with methylol groups on the surface were repeatedly washed with deionized water to remove low molecular weight compounds. To avoid interchain structuring processes in the grafted nanolayer, polypropylene microfibers were used with the residual moisture content of $11 \%$.

\section{Synthesis of hydrogels}

Aqueous solutions of poly-N-(hydroxymethyl) acrylamide (18-21\%), polyacrylamide (15-20\%) and gelatin $(10-15 \%)$ were used to obtain hydrogels; they were mixed in compliance with the specified ratios. To obtain a sample of hydrogel with a volume of $15 \mathrm{~cm}^{3}$, the resulting mixture was homogenized, the value of the hydrogen index was adjusted to $\mathrm{pH} 2-$ 4 by dropwise introduction of $0.15-0.62 \mathrm{~mL}$ of $10 \%$ hydrochloric acid solution (its amount depends on the amount of gelatin in the composition) and heated for a certain time in a sealed reactor at the temperature of $50-70^{\circ} \mathrm{C}$. In the course of production of the reinforced hydrogels, modified polypropylene microfiber was further introduced into the mixture. According to the results of morolin analysis of the finished hydrogel sample, the acrylamide content was $35 \mathrm{mg}$ per gram of hydrogel. Permitted levels of acrylamide in hydrogels for external use are 50$55 \mathrm{mg} / \mathrm{g}$.

\section{Determination of swelling degree}

Swelling degree of the hydrogel samples (i.e. the ratio of the mass of water to the mass of polymers in the hydrogel sample) was determined by gravimetric method at $20^{\circ} \mathrm{C}$ in distilled water. The calculation of swelling degree $(\alpha)$ was performed by using the following formula:

$$
\alpha(\%)=\frac{m_{t}-m_{0}}{m_{0}} \times 100,
$$

where $\mathrm{m}_{\mathrm{t}}$ is the mass of the swollen hydrogel sample at time $t$; and $\mathrm{m}_{0}$ is the mass of the polymer-gelling agent in the test sample.

\section{Filling of hydrogel samples with the drug}

Filling of hydrogel samples with the drug (novocaine or lidocaine) was performed by swelling them in a solution of the drug. Maximum drug content was $2 \%$ at a swelling rate of $6.14 \mathrm{~g}$ of water/g of polymer-gelling agents according to the method described elsewhere [12].

\section{Study of the release of the drug}

Study of the release of the drug (novocaine or lidocaine) from hydrogel samples were performed as follows: measuring the optical density at $\lambda=262 \mathrm{~nm}$ and $\lambda=290 \mathrm{~nm}$ for lidocaine and novocaine, respectively. Quantitative evaluation of the drug content in the solution was performed using the appropriate calibration dependences: $\mathrm{C}_{\mathrm{n}}=17.263 \cdot \mathrm{D}-$ -0.0534 and $\mathrm{C}_{1}=688.82 \cdot \mathrm{D}+0.0086$ for lidocaine and novocaine, respectively. Having obtained these values, the amount of drug remaining in the hydrogel was calculated.

\section{Water retention}

Samples of microfiber $(0.2 \mathrm{~g})$ were placed in a perforated polypropylene cylinder. The microfiber was compressed in the cylinder to the specified volume by means of a rod. A microfiber cylinder was placed in a Dogadkin device and the amount of absorbed water was determined. Measurements were performed every 15 minutes and stopped when the difference between the previous and next measurement was absent.

The calculation of the water content $\gamma$ was performed by the following formula:

$$
\gamma=\frac{\mathrm{m}_{\mathrm{v}}}{\mathrm{m}_{0}}
$$

where $m_{v}$ is the mass of the microfiber sample at time $\mathrm{t}$; and $\mathrm{m}_{0}$ is the mass of the dry microfiber sample.

Free surface energy of polypropylene planar surfaces

Free surface energy of polypropylene planar surfaces was determined by measuring the wetting angle by the method of two liquids (water and methylene iodide) [8].

\section{Results and discussion}

Modification of polypropylene microfiber

Polypropylene is a hardly reactive polymer characterized by a very low free surface energy. Without special surface treatment, it is poorly wetted with water, and thus the microfibers cannot be evenly distributed throughout the aqueous matrix of a hydrogel. For this reason, the surface of polypropylene microfibers used as a reinforcement of hydrogels requires modification that enables formation of a layer containing hydrophilic functional groups $[13,14]$. It can be achieved, e.g. by using radical initiators in particular heterofunctional polyperoxides [11,15]. This opens wide opportunities for grafting the fragments of natural and/or synthetic polymers to the surface. It is also possible to modify the surface of grafted polymer layers through the subsequent initiation processes of radical polymerization of functional monomers from the peroxidized surface [11]. All these studies were performed using planar surfaces of polyolefins. The variation of surface properties was monitored by changes in their free surface energy and confirmed by ellipsometry, ATR FTIR spectroscopy and atomic 

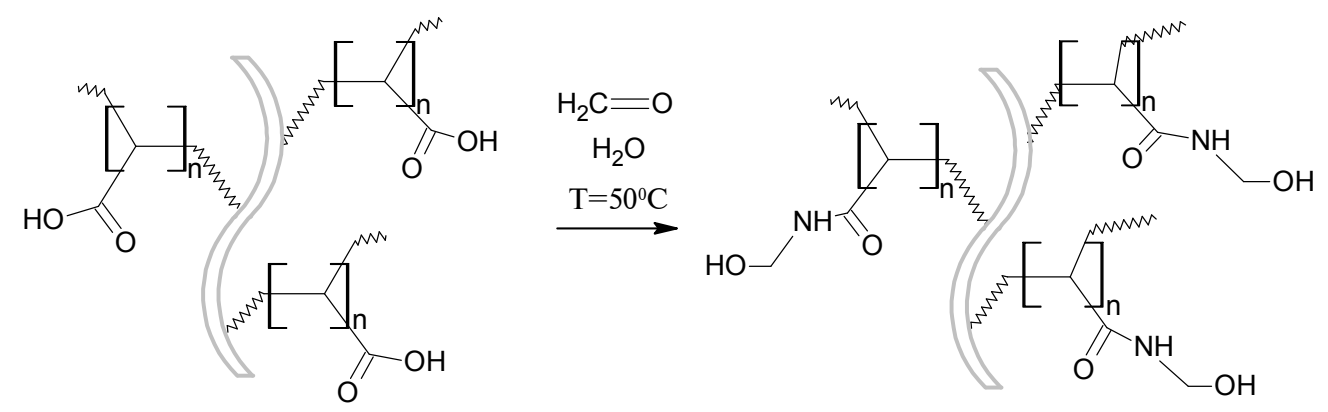

Fig. 2. Scheme of polymer-analogical transformations in a nanolayer of polyacrylamide (grafted to the surface of polypropylene) when interacting with formaldehyde

force microscopy. However, in this work we studied the processes of microfiber modification, so it was not possible to use all these methods, except ATR FTIR spectroscopy. To control the modification processes, we used ATR FTIR spectroscopy and elemental analysis to estimate the value of specific water retention at different stages of modification. At the same time, changes in surface properties of planar polypropylene samples were modified and monitored under the same conditions.

The scheme of modification of polypropylene microfiber (Fig. 1) includes the following stages:

- modification (peroxidation) of the surface of polypropylene with copolyperoxide PA-OMA;

- grafting of polymer chains of polyacrylamide (by initiating radical polymerization by peroxide groups localized on the surface of peroxidized polypropylene);

- obtaining reactive groups on the surface of modified polypropylene through polymer-analogical transformations in the grafted layers.

Changes in the free energy of the surface of planar samples, value of specific water retention for the fiber at different stages of its modification, ATR FTIR spectroscopy and elemental analysis clearly confirmed the successful surface modification of polypropylene microfibers.

Although polyacrylamide is generally a nonreactive polymer, its amide groups can interact with formaldehyde under relatively mild conditions and form reactive methylol groups. This reaction on the surface of the polyacrylamide-modified microfibers was conducted under the conditions of a previously developed method for the synthesis of poly-N(hydroxymethyl)acrylamide [10] according to the scheme shown in Fig. 2.

The ATR FTIR spectra of a polypropylene microfiber whose surface was modified with polyacrylamide and poly-N-(hydroxymethyl)acrylamide are shown in Fig. 3.

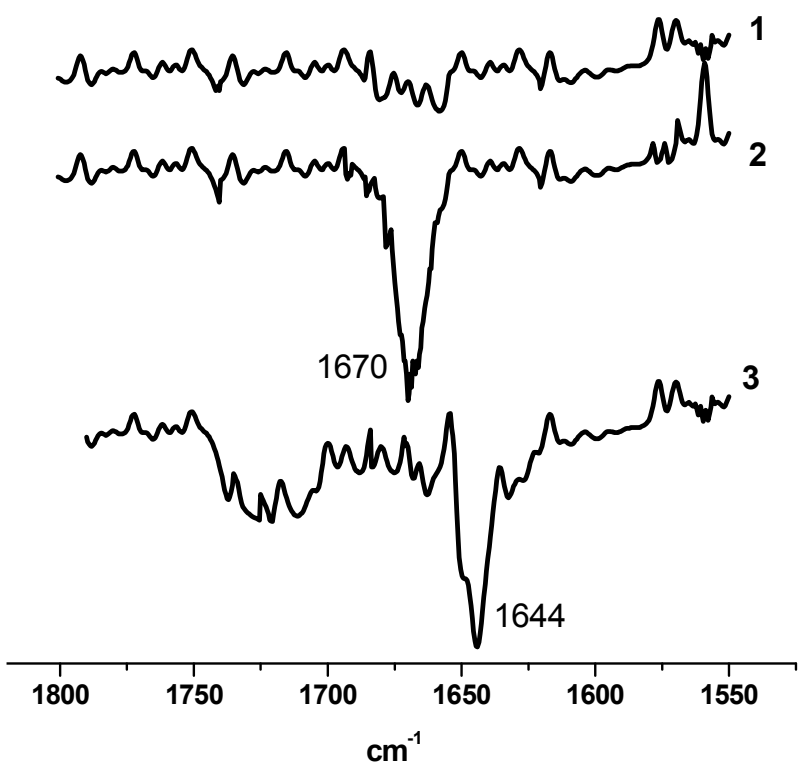

Fig. 3. ATR FTIR spectra of polypropylene microfiber: 1 - unmodified; 2 - modified with polyacrylamide; and

3 - modified with poly-N-hydroxymethylolacrylamide

The presence of the absorption bands with maxima at $1670 \mathrm{~cm}^{-1}$ and $1644 \mathrm{~cm}^{-1}$ (which can be attributed to the valence vibrations of the carbonyl group $=\mathrm{C}=\mathrm{O}$ and $=\mathrm{NH}$ in the amide group) suggests the grafting of nanolayers of polyacrylamide to the surface of polypropylene activated by PA-OMA. It also confirms a significant proportion of its conversion into poly-N-(hydroxymethyl)acrylamide after reaction with formaldehyde.

Table 1 shows the parameters of free surface energy for planar samples of polypropylene and water retention values for microfibers with a modified surface. Modification of polypropylene surface via nanolayers of polyacrylamide leads to its hydrophilization. This can be confirmed by a significant increase values of the hydrogen component of free surface energy (from $2.8 \pm 1.0 \mathrm{mN} / \mathrm{m}$ to $29.8 \pm 1.0 \mathrm{mN} / \mathrm{m}$ ) and an increase the water retention of microfiber by 11.0-15.2 times. 
Table 1

Surface characteristics of planar samples of polypropylene and microfiber

\begin{tabular}{|c|c|c|c|c|c|}
\hline \multirow[t]{2}{*}{ The nature of the surface } & \multicolumn{3}{|c|}{$\begin{array}{c}\text { Components and total free } \\
\text { surface energy, } \mathrm{mN} / \mathrm{m}\end{array}$} & \multirow{2}{*}{$\begin{array}{l}\text { The share of } \\
\text { the modified } \\
\text { surface, } \%\end{array}$} & \multirow{2}{*}{$\begin{array}{l}\text { Water retention, } \\
\mathrm{g}_{\text {water }} / \mathrm{g}_{\text {fiber }}\end{array}$} \\
\hline & $\lambda_{\mathrm{S}}{ }^{\mathrm{d}}$ & $\lambda_{\mathrm{S}}^{\mathrm{h}}$ & $\lambda_{\mathrm{S}}$ & & \\
\hline PP & 30.60 & 2.83 & 33.43 & - & $0.3-0.5$ \\
\hline $\mathrm{PP} \rightarrow \mathrm{PA}-\mathrm{OMA}$ & 31.62 & 5.25 & 36.88 & $97 \pm 2$ & $0.6-0.8$ \\
\hline $\mathrm{PP} \rightarrow \mathrm{PA}-\mathrm{OMA} \rightarrow$ polyacrylamide & 9.33 & 29.81 & 39.15 & $95 \pm 2$ & $8.0-8.6$ \\
\hline $\begin{array}{l}\mathrm{PP} \rightarrow \mathrm{PA}-\mathrm{OMA} \rightarrow \\
\rightarrow \text { (poly-N-(hydroxymethyl)acrylamide/polyacrylamide) }\end{array}$ & 12.50 & 25.41 & 37.91 & - & $10.0-10.6$ \\
\hline
\end{tabular}

Synthesis and properties of hydrogels based on polyacrylamide, poly- $N$ - (hydroxymethyl) acrylamide and gelatin

Previous studies have shown that the conditions for hydrogel formation due to the interchain reactions of polyacrylamide with poly-N-(hydroxymethyl)acrylamide are mainly determined by $\mathrm{pH}$, temperature, concentration of prepolymers and reaction time [10]. However, the introduction of components, such as gelatin and modified polypropylene microfiber, into the gel-forming composition requires additional studies.

Experiments on the selection of $\mathrm{pH}$ of the medium in the synthesis showed that the formation of hydrogels occurs during the structuring reaction in the range from 2 to 4 . At $\mathrm{pH}>4$, hydrogel formation did not occur at all. At $\mathrm{pH}<2$, hydrogels were formed; however, the samples were inhomogeneous and poorly reproducible. Obviously, it is related to the course simultaneously with the structuring of the hydrolysis processes of the functional groups.

The temperature range at which the synthesis of hydrogels was carried out was adjusted to maintain a certain balance between the rate of formation of a three-dimensional structure and the attempt to avoid the processes of hydrolysis of polymers. Previous studies have shown that hydrogels with a very heterogeneous, layered structure are formed in syntheses with gelatin at the temperatures of above $70^{\circ} \mathrm{C}$ as well as at low $\mathrm{pH}$. A decrease in temperature below $50^{\circ} \mathrm{C}$ causes a significant increase in the synthesis duration. Therefore, further syntheses were performed at the temperatures of $50-70^{\circ} \mathrm{C}$ and $\mathrm{pH} 2$.

The molecular weight of the prepolymers used for the synthesis of hydrogels was $55 \mathrm{kDa}$ and $40 \mathrm{kDa}$ for poly-N-(hydroxymethyl)acrylamide and polyacrylamide, respectively. At these values, aqueous solutions of prepolymers obeyed the laws of Newtonian fluids flow. That allowed changing their concentration in a wide range, avoiding the initial solutions of high viscosity. According to previous works, hydrogels based on polyacrylamide and poly$\mathrm{N}$-(hydroxymethyl)acrylamide with satisfactory physical and mechanical properties were obtained at their total concentration of $7.5-9.0 \%$ [10]. Inclusion of additional gelatin in the gel-forming composition significantly disturbed the balance of reactive groups and the formation of a hydrogel with similar properties. This process occurred at a minimum of total concentration (12\%) of gel-forming prepolymers (gelatin, polyacrylamide and poly-N(hydroxymethyl)acrylamide). On the other hand, the excess amount of gelling polymer also deteriorated the sorption characteristics and was not profitable for economic reasons.

These requirements limit the concentration range of prepolymers in the synthesis within the range of $12-14 \%$. Table 2 shows the individual properties of the obtained hydrogels depending on the conditions of their production.

Previous work [10] devoted to the synthesis of hydrogels based on polyacrylamide and poly-N(hydroxymethyl)acrylamide showed that the most effective structuring processes take place at the ratio of macro-linker (poly-N-(hydroxymethyl)acrylamide) to polyacrylamide equal to $0.9-1.4$ to 1.0 , respectively. To establish the optimal ratios of prepolymers, the content dependence of the gel fraction in the samples of hydrogels obtained were investigated at different values of gelatin (Fig. 4).

There is a well-defined extremal dependence of the content of the gel fraction on the concentration of gelatin in the gel-forming composition. A maximum involvement of prepolymer macromolecules in the structuring processes of hydrogels was observed (i.e. gel fractions in the range of $70-80 \%$ ) at a gelatin content of $2.1-4.5 \%$.

In this case, the concentration of gelatin in the gel-forming composition depends not only on the structuring processes, but also on the degree of swelling in water (Fig. 5).

The sample of hydrogel obtained at $2.1 \%$ of gelatin (Fig. 5, a, curve 2) at which the minimum 
Physical-mechanical properties of hydrogels at various synthesis conditions ${ }^{*}$

\begin{tabular}{c|c|c|c|c|c|c|c}
\hline \multirow{2}{*}{$\begin{array}{c}\text { Number of } \\
\text { hydrogel }\end{array}$} & \multicolumn{3}{|c|}{ Concentration, \% } & \multirow{2}{*}{$\mathrm{T},{ }^{0} \mathrm{C}$} & \multicolumn{2}{|c|}{ Swelling, g water/g polymer } & \multirow{2}{*}{ Strength limit, kPa } \\
\cline { 2 - 3 } & $\mathrm{CT}$ & PAA & Gelatin & & $2 \mathrm{~h}$ & 10 days & \\
\hline 1 & 7 & 7 & 0 & 60 & 8.94 & 32.21 & $9800 \pm 25$ \\
\hline 2 & 7 & 0 & 7 & 60 & 12.12 & 35.99 & $4000 \pm 10$ \\
\hline 3 & 7 & 4.9 & 2.1 & 60 & 9.83 & 23.05 & $14000 \pm 40$ \\
\hline 4 & 7 & 7 & 0 & 70 & 8.92 & 26.19 & $11300 \pm 35$ \\
\hline 5 & 7 & 0 & 7 & 70 & 10.54 & 28.24 & $10085 \pm 25$ \\
\hline 6 & 7 & 4.9 & 2.1 & 70 & 8.55 & 18.1 & $23500 \pm 55$ \\
\hline 7 & 7 & 7 & 0 & 50 & 11.8 & 35.14 & $3720 \pm 15$ \\
\hline 8 & 7 & 0 & 7 & 50 & 14.29 & 42.15 & - \\
\hline 9 & 7 & 4.9 & 2.1 & 50 & 10.4 & 28.95 & $10302 \pm 25$ \\
\hline 10 & 7 & 2.1 & 4.9 & 70 & 9.6 & 22.15 & $12800 \pm 23$ \\
\hline
\end{tabular}

* Note - duration of hydrogel synthesis was 12 hours; $\mathrm{pH} 2$.

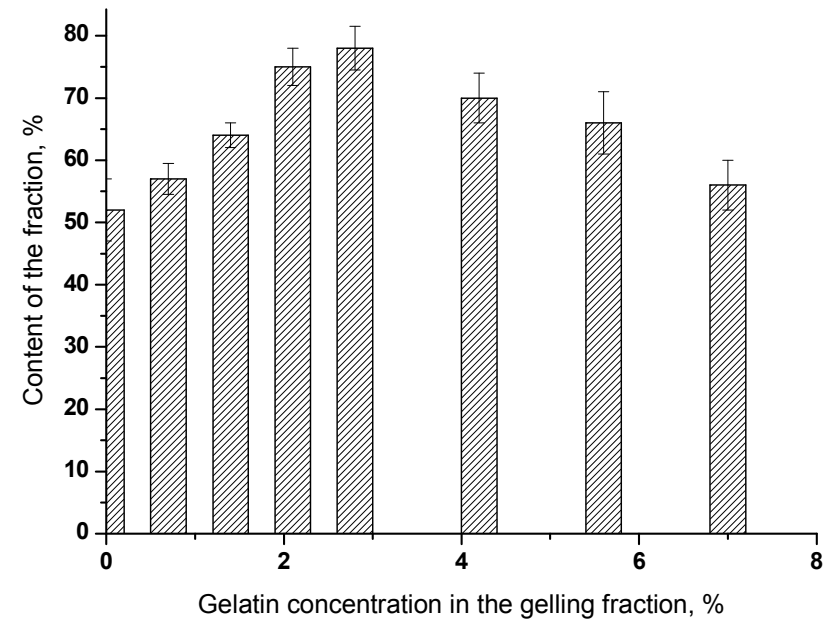

Fig. 4. The content of the gel fraction in the samples of hydrogels obtained at different gelatin contents in the gel-forming composition. Conditions of the samples preparation: $\mathrm{T}=70^{\circ} \mathrm{C}, \mathrm{pH}$ 2, duration of the synthesis of 12 hours

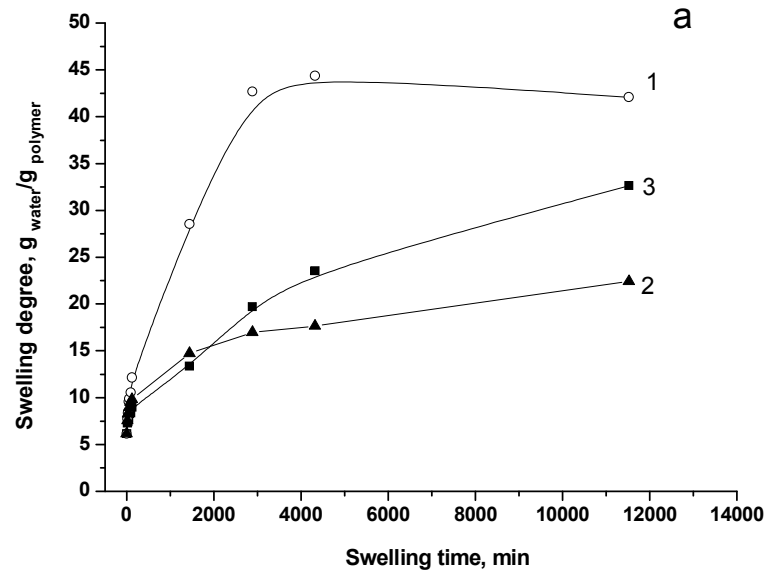

content of sol fractions is observed shows a minimum value of the equilibrium degree of swelling. It is less even in comparison with the hydrogel which is synthesized in comparative conditions without gelatin (Fig. 5, a, curve 3). Curve 1 in Fig. 5, a shows the change in the degree of swelling for the sample of hydrogel obtained by structuring poly-N(hydroxymethyl)acrylamide and gelatin in a ratio of 1 to 1 The absence of acrylamide prepolymer in the composition, namely, when there is only a crosslinker and gelatin in the reaction mixture (synthesis at a temperature of $60^{\circ} \mathrm{C}$ ), leads to the formation of a hydrogel with high values of the swelling rate. However, the nature of the swelling curve indicates that the hydrogel is not fully structured and it partially dissolves in the process of swelling.

As the synthesis temperature is increased up to $70^{\circ} \mathrm{C}$ (Fig. 5,b, curve 1), the hydrogel of the same composition does not show signs of dissolution.

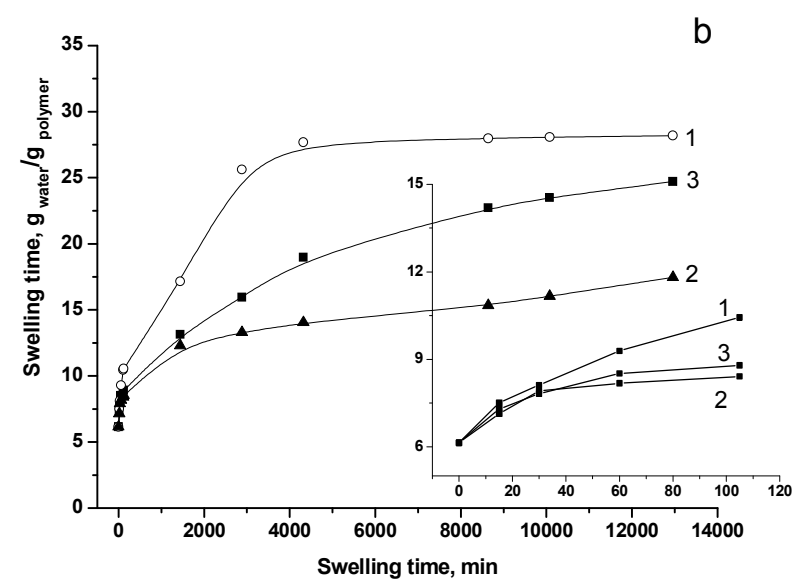

Fig. 5. Time dependence of the swelling degree for the samples of hydrogels: a - at the synthesis temperature of $60^{\circ} \mathrm{C}$; $\mathrm{b}-$ at the synthesis temperature of $70^{\circ} \mathrm{C}$. The content of components in the gelling composition is: $1-$ PAA $0 \%$, CT $7 \%$ and gelatin $7 \%$; 2 - PAA $4.9 \%$, CT $7 \%$ and gelatin $2.1 \%$; and $3-$ PAA $7 \%$, CT $7 \%$ and gelatin $0 \%$

O.V. Maikovych, N.G. Nosova, M.V. Yakoviv, I.A. Dron, A.V. Stasiuk, V.Ya. Samaryk, S.M. Varvarenko, S.A. Voronov 
However, a relatively high initial rate of swelling persists in this case. It reaches an equilibrium degree of swelling in $3000 \mathrm{~min}$, while hydrogels of another composition with $2.1 \%$ of gelatin and without it do not reach swelling equilibrium in $14000 \mathrm{~min}$ (Fig. 5,b, curves 2 and 3). The insert in Fig. 5,b shows the swelling curves, characterizing the sample of hydrogel with gelatin content of $2.1 \%$, is able to absorb $12.5 \%$ and $40 \%$ of the liquid after 15 minutes and 60 minutes of the synthesis, respectively. These values are sufficient to ensure that the hydrogel sample absorbs the appropriate amount of aqueous drug solution and its further use as a hydrogel therapeutic dressing.

The change in the mechanical properties of the hydrogel sample was determined by the change in the value of a maximum load after which the destruction occurs. Figure 6 shows the dependence of the maximum load before the destruction for the samples of hydrogels no. 3, 6 and 9 (numbering is given in Table 2) with the same composition, differing only by the synthesis temperature. The obtained values allow us to conclude that the mechanical properties significantly improve with increasing synthesis temperature. There is an increase by 22.3 times for samples obtained at the temperatures of $60^{\circ} \mathrm{C}$ and $70^{\circ} \mathrm{C}$ as compared with analogues ones synthesized at $50^{\circ} \mathrm{C}$. The magnitudes of the maximum load differ insignificantly, in contrast to the swelling for temperatures of $60^{\circ} \mathrm{C}$ and $70^{\circ} \mathrm{C}$. This fact can be explained by an increase in the number of crosslinking nodes in the polymer mesh of the hydrogel. This causes a growth of the mechanical properties of the hydrogel and does not affect the magnitude of the degree of swelling.

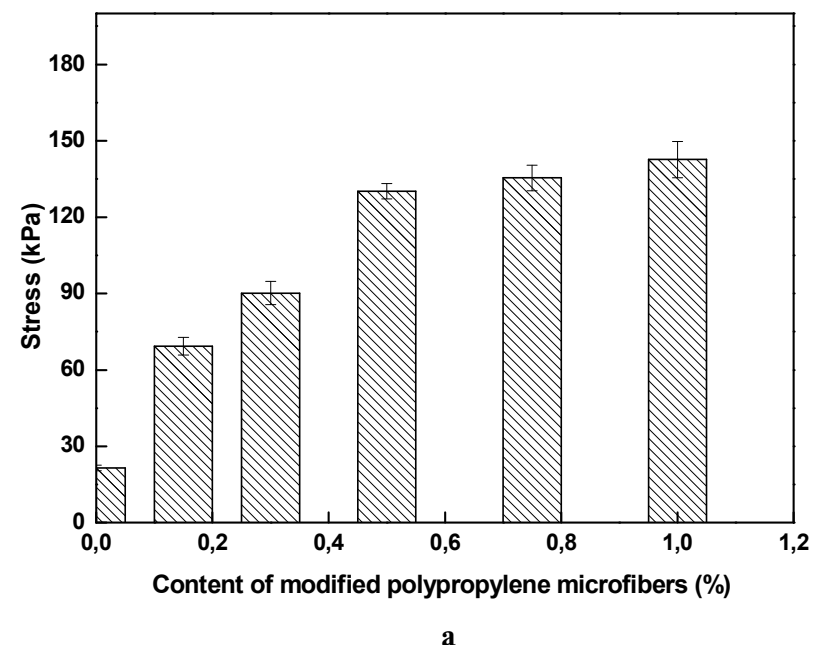

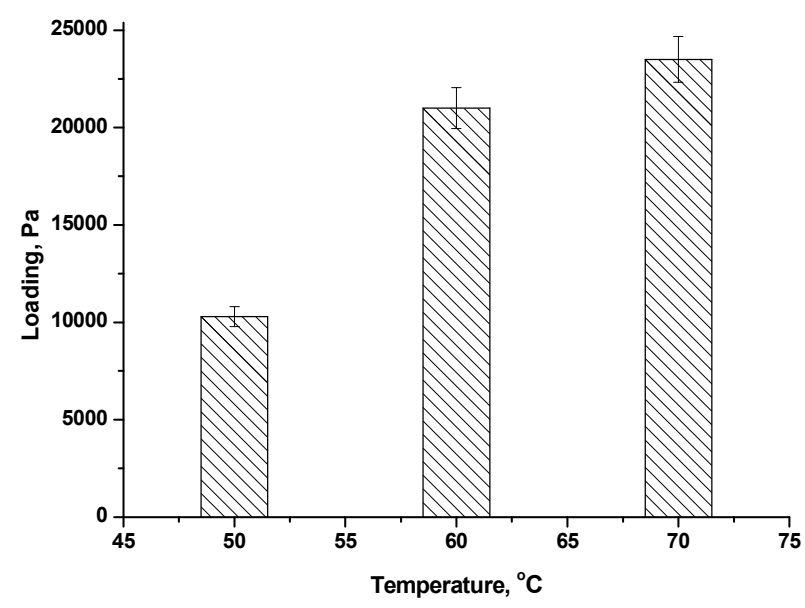

Fig. 6. Dependence of the maximum load for hydrogel samples on the synthesis temperature. Conditions of the samples preparation: $\mathrm{pH} 2$, synthesis time of 12 hours, total concentration of components of $14 \%$, PAA content of $4.9 \%$,

CT content of $7 \%$, and gelatin content of $2.1 \%$

Thus, the influence of the production conditions on the characteristics of hydrogels based on polyacrylamide, poly- $\mathrm{N}$-(hydroxymethyl)acrylamide and gelatin has been established. The minimum limits of concentrations of components, temperature range, and $\mathrm{pH}$ of the medium at which the formation of a hydrogel with satisfactory physicochemical and mechanical properties is possible have been revealed.

Changes in mechanical properties of reinforced hydrogels with modified polypropylene microfiber

The effect of the modified polypropylene microfibers on the properties of composite hydrogels was evaluated by studying the strength of the hydrogel

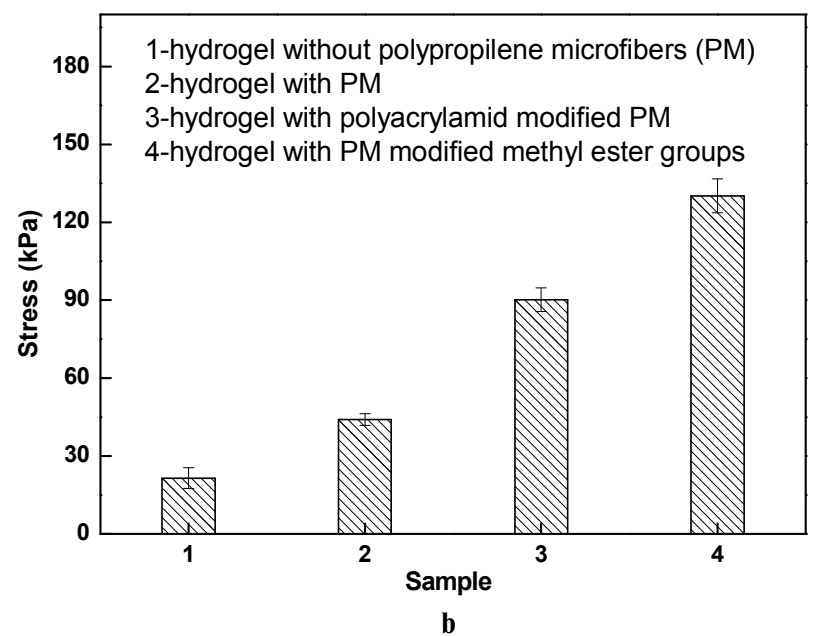

Fig. 7. Dependences of the maximum stress on the content of modified polypropylene microfiber in the hydrogel sample (a); and on the modification stages of reinforcing microfiber (b). Conditions of the sample preparation: $\mathrm{pH} 2$, reaction time of

12 hours, temperature of $70^{\circ} \mathrm{C}$, total concentration of components of $14 \%$, PAA content of $4.9 \%$, CT content of $7 \%$, and gelatin content of $2.1 \%$ 
samples obtained with different contents of microfibers. After introduction of $0.1-0.5 \%$ of the modified microfiber into the composition, we observed an increase in the maximum strain (before destruction) of the hydrogel by $3-7$ times in comparison with the sample without microfiber (Fig. 7,a).

A further increase of fibers within $0.5-1 \%$ leads to an increase in the strength by only $5-10 \%$. Therefore, $0.5 \%$ of microfibers in the hydrogel can be considered the optimal concentration at which a maximum increase in the strength was achieved.

Maximum values of stress (before failure), depending on the modification stage of the reinforcing microfiber surface for hydrogels, were observed under comparative conditions (Fig. 7,b). Introduction of polypropylene microfibers modified with polyacrylamide and treated with formaldehyde into hydrogel (Fig. 7,b: sample 4 contains reactive methylol groups in the surface layer) led to a threefold increase (from 40 to $130 \mathrm{kPa}$ ) in the maximum stress against failure as compared with the hydrogel with microfibers whose surface was modified by polyperoxide (Figure 7,b, sample 2).

After introduction of microfibers with surface modified by polyacrylamide (Figure 7, b, sample 3), the mechanical strength of the hydrogel was increased twice as compared with the sample 2. In this case, such behavior can be explained by the attraction of amino groups in the grafted polyacrylamide on the surface in the overall structure of the polymer hydrogel frame.

\section{Investigation of drug release}

It is known that an exudate releases in wounds, cuts or areas of infection or inflammation, the exudate being a fluid that composes of serum, fibrin and white blood cells. Applied hydrogels can absorb the exudate and a drug can be transferred into the affected area through the exudate. In this study, novocaine (procaine, 2-(diethylamino)ethyl 4-aminobenzoate) and lidocaine (xylocaine, N-(2,6-dimethylphenyl)$\mathrm{N}$ ', N' -diethylglycinamide) were chosen as anesthetics drugs to study the processes of absorption and drug release into the aqueous medium.

Lidocaine release from the hydrogel after 1 hour was $10-20 \mathrm{wt} . \%$; is reached $30-40 \%$ after 6 hours (Fig. 8,a). A maximum lidocaine release, as compared with its initial content in the hydrogel, was 7080 wt. $\%$ after 24 hours. In the case of novocaine, the release of $10-15$ wt.\% and $20-25$ wt.\% was observed after 1 and 6 hours, respectively (Fig. 8,b).

We can hypothesize that the release of novocaine was slower than that of lidocaine was most likely due to the presence of a primary amino group in the structure of its molecule. The free methylol groups of poly-N-(hydroxymethyl)acrylamide are able to bind with this primary amino group. This causes a slower release of novocaine. Only 30$35 \mathrm{wt} . \%$ of novocaine was released after 24 hours as compared with its initial content in the hydrogel. The investigation of the drug release from the polymer matrix of the hydrogel showed that the release of novocaine and lidocaine was slowed down which provides a new system with prolonged drug delivery.

\section{Conclusions}

This paper described the conditions for preparation of polypropylene hydrogels reinforced with microfiber using biopolymer gelatin. The obtained hydrogels showed satisfactory physical and mechanical characteristics. Based on the developed hydrogel material, it is possible to create hydrogel bandages with prolonged and controlled delivery of therapeutic drugs of different nature. The biopolymer

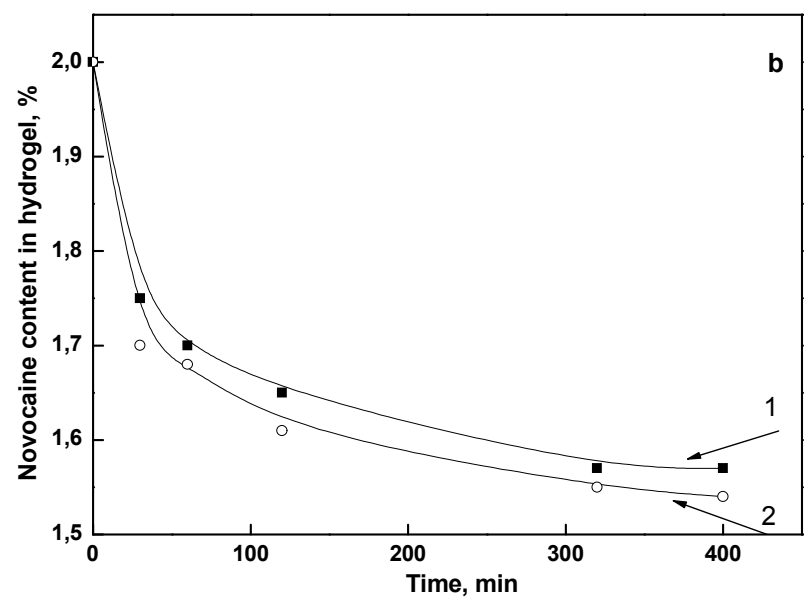

Fig. 8. Kinetic curves of the release of lidocaine (a) and novocaine (b) from hydrogels with different content of gelatin in hydrogel: 1 - without gelatin (no. 4 in Table 2); $2-2.1 \%$ (no. 6 in Table 2); and $3-4.2 \%$ (no. 10 in Table 2)

O.V. Maikovych, N.G. Nosova, M.V. Yakoviv, I.A. Dron, A.V. Stasiuk, V.Ya. Samaryk, S.M. Varvarenko, S.A. Voronov 
in the structure of a polymer framework of the hydrogel will promote its natural degradation, in contrast to hydrogels based on synthetic polymers.

\section{REFERENCES}

1. Dhivya S., Padma V.V., Santhini E. Wound dressings a review // BioMedicine. - 2015. - Vol. 5. - Article No. 22.

2. Novel biomaterial strategies for controlled growth factor delivery for biomedical applications / Wang Z., Wang Z., Lu W.W., Zhen W., Yang D., Peng S. // NPG Asia Mater. - 2017. Vol.9. - Article No. e435.

3. Physically crosslinked-sacran hydrogel films for wound dressing application / Wathoni N., Motoyama K., Higashi T., Okajima M., Kaneko T., Arima H. // Int. J. Biol. Macromol. 2016. - Vol.89. - P.465-470.

4. Technological features in obtaining highly effective hydrogel dressings for medical purposes / Grytsenko O., Pokhmurska A., Suberliak S., Kushnirchuk M., Panas M., Moravskyi V., Kovalchuk R. // East. Eur. J. Enterprise Technol. - 2018. - Vol.6. - No. 6. - P.6-13.

5. Kovalenko O.M., Kovalenko A.O., Osadcha O.I. Vplyv ranovykh pokryttiv na $\mathrm{pH}$ rany pry poverkhnevykh opikakh shkiry // Klinicheskaya Khirurgiya. - 2017. - Vol.2. - P.28-30.

6. Oyen M.L. Mechanical characterisation of hydrogel materials // Int. Mater. Rev. - 2014. - Vol.59. - No. 1. - P.44-59.

7. UV LED curing of hydrogel-modified textiles with high anti-fouling resistance / Naemuddin N.H., Mizi F.M., Suradi S.S., Jamaluddin J., Othman M.H.D., Adrus N. // J. Photopolym. Sci. Technol. - 2019. - Vol.32. - No.5. - P.699-704.

8. Polypropylene surface peroxidation with heterofunctional polyperoxides / Nosova N., Roiter Y., Samaryk V., Varvarenko S., Stetsyshyn Y., Minko S., Stamm M., Voronov S. // Macromol. Symp. - 2004. - Vol.210. - P.339-348.

9. Emulsion copolymers of methyl acrylate and decyl (meth)acrylate: Synthesis and properties / Kovalenko T.P., Serdiuk V.O., Vostres V.B., Matiko H.F. // Voprosy Khimii i Khimicheskoi Tekhnologii. - 2019. - No. 6. - P.99-106.

10. Porysti poliakrylamidni gidrogeli - oderzhann'ya ta vlastyvosti [Porous polyacrylamide hydrogels: preparation and properties] / Nosova N.G., Samaryk V.J., Varvarenko S.M., Ferens M.V., Voronovska A.V., Nagornyak M.I., Khomyak S.V., Nadashkevych Z.J., Voronov S.A. // Voprosy Khimii i Khimicheskoi Tekhnologii. - 2016. - No. 5-6. - P.78-86.

11. Formation of polymer nanolayers with special properties at polymer surfaces / Samaryk V., Varvarenko S., Tarnavchyk I., Nosova N., Puzko N., Voronov S. // Macromol. Symp. - 2008. - Vol.267. - No. 1. - P.113-117.
12. Sorption capable film coatings with variable conductivity / Grytsenko O., Spisak E., Dulebova L., Moravskii V., Suberlyak O. // Mater. Sci. Forum. - 2015. - Vol.818. - P.97-100.

13. Reductants for polyperoxides to accelerate degradation at elevated temperatures / Sato E., Yuri M., Matsumoto A., Horibe H. // Polym. Degrad. Stab. - 2019. - Vol.162. - P.47-54.

14. Nanostructured polystyrene films engineered by plasma processes: surface characterization and stem cell interaction / Mattioli S., Martino S., D’Angelo F., Emiliani C., Kenny J.M., Armenato I. // J. Appl. Polym. Sci. - 2014. - Vol.131. - Article No. 40427.

15. Formation of coatings with tailored properties on polyperoxide-modified polymeric surfaces / Samaryk V., Voronov A., Tarnavchyk I., Varvarenko S., Nosova N., Budishevska O., Kohut A., Voronov S. // Prog. Org. Coat. - 2012. - Vol.74. - No. 4. P.687-696.

Received 20.08.2020

\section{КОМПОЗИТНІ МАТЕРІАЛИ НА ОСНОВІ ПОЛІАКРИЛАМІДУ ТА ЖЕЛАТИНУ АРМОВАНІ ПОЛІПРОПІЛЕНОВИМ МІКРОВОЛОКНОМ}

О.В. Майкович, Н.Г. Носова, М.В. Яковів, І.А. Дронь, А.В. Стасюк, В.Я. Самарик, С.М. Варваренко, С.А. Воронов

Встановлено умови одержання композитного гідрогелю на основі поліакриламіду та желатину, який для підвищення його міцності армований поліпропіленовим мікроволокном. Встановлено умови модифікації поліпропіленового мікроволокна, за яких відбувається гідрофілізація його поверхні, що підтверджується суттєвим збільшенням величини водоутримання мікроволокном у $11,0-15,2$ разів. За цих же умов спостерігалось зростання значень водневої складової вільної поверхневої енергії на планарних зразках пол-

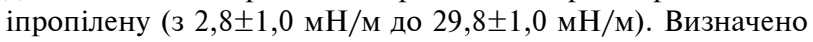
оптимальні умови (мінімальні граничні межі концентрацій компонентів, температурний діапазон, $\mathrm{pH}$ середовища), при яких можливе утворення гідрогелю на основі поліакриламіду та желатину із задовільними фізико-хімічними та механічними властивостями. Одержано композитний гідрогель на основі поліакриламіду та желатину, армований модифікованим поліпропіленовим мікроволокном, та встановлено, що введення модифікованого мікроволокна збільшує межі початку руйнування з 20-30 до 130 кПа. Результати вивчення процесів вивільнення лікарських речовин з гідрогелю вказують на можливість використання одержаних композитів як матриць для створення гідрогелевої лікувальної пов'язки з функцією пролонгованої доставки лікарських препаратів.

Ключові слова: гідрогель, поліакриламід, желатин, поліпропілен, мікроволокно, доставка лікарських препаратів. 


\section{COMPOSITE MATERIALS BASED ON POLYACRYLAMIDE AND GELATIN REINFORCED WITH POLYPROPYLENE MICROFIBER}

O.V. Maikovych ", N.G. Nosova, M.V. Yakoviv, I.A. Dron, A.V. Stasiuk, V.Ya. Samaryk, S.M. Varvarenko, S.A. Voronov

Ukraine Lviv Polytechnic National University, Lviv, Ukraine

* e-mail: olha.v.maikovych@lpnu.ua

The conditions for preparation of a composite hydrogel based on polyacrylamide and gelatin, which is reinforced with polypropylene microfiber, were determined to increase its strength. The conditions of modification of polypropylene microfiber were established under which its surface is hydrophilized, which was confirmed by a significant increase in the water retention of microfiber by 11.0-15.2 times. Under the same conditions, an increase in the values of the hydrogen component of free surface energy on planar samples of polypropylene was observed (from $2.8 \pm 1.0 \mathrm{mN} \mathrm{m}^{-1}$ to $29.8 \pm 1.0 \mathrm{mN} \mathrm{m} \mathrm{m}^{-1}$ ). Optimal conditions (minimum limits of component concentrations, temperature range, and $\mathrm{pH}$ of a medium) were determined, under which a hydrogel based on polyacrylamide and gelatin with satisfactory physicochemical and mechanical properties can be formed. A composite hydrogel, based on polyacrylamide and gelatin reinforced with modified polypropylene microfiber, was prepared. It was found that the introduction of modified microfiber increases the limits of the beginning of destruction from $20-30$ to $130 \mathrm{kPa}$. The results of the investigation of the drug release from the hydrogel indicated that the obtained composites can be used as matrices to create a hydrogel therapeutic bandages with the function of prolonged drug delivery.

Keywords: hydrogel; polyacrylamide; gelatin; polypropylene; microfiber; drug delivery.

\section{REFERENCES}

1. Dhivya S, Padma VV, Santhini E. Wound dressings - a review. Biomedicine. 2015; 5(4): 22. doi: 10.7603/s40681-015-0022-9.

2. Wang Z, Wang Z, Lu WW, Zhen W, Yang D, Peng S. Novel biomaterial strategies for controlled growth factor delivery for biomedical applications. NPG Asia Mater. 2017; 9: e435. doi: 10.1038/am.2017.171.

3. Wathoni N, Motoyama K, Higashi T, Okajima M, Kaneko T, Arima H. Physically crosslinked-sacran hydrogel films for wound dressing application. Int J Biol Macromol. 2016; 89: 465-470. doi: 10.1016/j.ijbiomac.2016.05.006.

4. Grytsenko O, Pokhmurska A, Suberliak S, Kushnirchuk M, Panas M, Moravskyi V, et al. Technological features in obtaining highly effective hydrogel dressings for medical purposes. East Eur J Enterprise Technol. 2018; 6(6): 6-13. doi: 10.15587/1729-4061.2018.150690.

5. Kovalenko OM, Kovalenko AO, Osadcha OI. Vplyv ranovykh pokryttiv na $\mathrm{pH}$ rany pry poverkhnevykh opikakh shkiry [Impact of the wound coverings on the wound $\mathrm{pH}$ in superficial burns of the skin]. Klinicheskaya Khirurgiya. 2017; 2: 28-30. (in Ukrainian).
6. Oyen ML. Mechanical characterisation of hydrogel materials. Int Mater Rev. 2014; 59(1): 44-59. doi: 10.1179/1743280413y.0000000022.

7. Naemuddin NH, Mizi FM, Suradi SS, Jamaluddin J, Othman MH, Adrus N. UV LED curing of hydrogel-modified textiles with high anti-fouling resistance. J Photopolym Sci Technol. 2019; 32: 699-704. doi: 10.2494/photopolymer.32.699.

8. Nosova N, Roiter Y, Samaryk V, Varvarenko S, Stetsyshyn Y, Minko S, et al. Polypropylene surface peroxidation with heterofunctional polyperoxides. Macromol Symp. 2004; 210: 339-348. doi: 10.1002/masy.200450638.

9. Kovalenko TP, Serdiuk VO, Vostres VB, Matiko HF. Emulsion copolymers of methyl acrylate and decyl (meth)acrylate: synthesis and properties. Voprosy Khimii i Khimicheskoi Tekhnologii. 2019; (6): 99-106. doi: 10.32434/0321-4095-2019-127-6-99-106.

10. Nosova NG, Samaryk VJ, Varvarenko SM, Ferens MV, Voronovska AV, Nagornyak MI, et al. Porysti poliakrylamidni gidrogeli - oderzhann'ya ta vlastyvosti [Porous polyacrylamide hydrogels: preparation and properties]. Voprosy Khimii $i$ Khimicheskoi Tekhnologii. 2016; (5-6): 78-86. (in Ukrainian).

11. Samaryk V, Varvarenko S, Tarnavchyk I, Nosova N, Puzko N, Voronov S. Formation of polymer nanolayers with special properties at polymer surfaces. Macromol Symp. 2008; 267: 113-117. doi: 10.1002/masy.200850721.

12. Grytsenko O, Spisak E, Dulebova L, Moravskii V, Suberlyak O. Sorption capable film coatings with variable conductivity. Mater Sci Forum. 2015; 818: 97-100. doi: 10.4028/www.scientific.net/msf.818.97.

13. Sato E, Yuri M, Matsumoto A, Horibe H. Reductants for polyperoxides to accelerate degradation at elevated temperatures. Polym Degrad Stab. 2019; 162: 47-54.

doi: 10.1016/j.polymdegradstab.2019.01.030.

14. Mattioli S, Martino S, D’Angelo F, Emiliani C, Kenny JM, Armenato I. Nanostructured polystyrene films engineered by plasma processes: surface characterization and stem cell interaction. J Appl Polym Sci. 2014; 131: 40427. doi: 10.1002/app.40427.

15. Samaryk V, Voronov A, Tarnavchyk I, Varvarenko S, Nosova N, Budishevska O, et al. Formation of coatings with tailored properties on polyperoxide-modified polymeric surfaces. Prog Org Coat. 2012; 74: 687-696.

doi: 10.1016/j.porgcoat.2011.07.015. 